\title{
Relationship between school culture and students' performance in French in selected secondary schools in Kenya
}

Omusonga, T. O., Kazadi, I.M E Indoshi, F. C.

\begin{abstract}
School culture refers to a set of accepted beliefs and norms governing people's conduct in a school. Schools with a culture that favors teaching and learning French tend to have a longer history of offering French subject characterized by high expectations for and recognition of academic and co-curricula achievement, parental involvement, and career guidance and counseling. Such schools also tend to perform better in French in national examinations compared to schools without a French culture. However, not a single study in Kenya has explored the role school culture may play in ameliorating the pathetic performance witnessed in French Kenya Certificate of Secondary Education (KCSE) examination, whereby $60 \%$ of candidates fail to attain the minimum required grade of $\mathrm{C}+$ to enable them join universities in the country. This necessitates a study of this nature whose purpose was to determine the relationship between school culture and students' performance in French in selected secondary schools in Kenya.
\end{abstract}

The study is based on correlation design. It was carried out in 16 secondary schools offering French in Western Province of Kenya, selected by stratified random sampling to include provincial, district and private school categories. Saturated sampling technique was used to select 16 teachers of French and 327 students of French, from the 16 sample schools. Data was analyzed by use of descriptive statistics (means and standard deviations) and inferential statistics (Pearson's product moment correlation and $t$ test).

The study reached the conclusion that school culture and students' performance in French in Kenya Certificate of Secondary Education (KCSE) examination have a strong positive correlation. Therefore, developing a French culture within a school improves students' scores in French. Based on these findings, it is recommended that school authorities in collaboration with the teacher of French should inculcate in their institutions a culture which favors teaching and learning of French, especially by encouraging students to participate in French co-curricula activities such as drama and music festivals, French days, and cultural exchange programs, and by availing the necessary French curriculum materials, facilities and equipment. 


\section{Introduction}

School culture is a set of accepted beliefs and norms governing people's conduct in a school. When the beliefs and norms relate to teaching and learning French then it is proper to talk of a "French culture". While some schools offering French subject end up developing a French culture, others simply have no culture.

Establishing a French culture in a school cannot be an overnight affair; rather it takes a considerable amount of time that may require several years, thus this study considers the duration a school has been offering French subject as one of the indicators of French culture. The assumption is that the longer the time, the more established the French culture is within a school. Indeed, the history of teaching French in the country indicates that the subject was first introduced in prestigious schools (European, Asian and leading African schools), which were well endowed in terms of curriculum materials, facilities and equipment (Gicheri, 1983). This trend continued after independence and currently we now have French being offered in all national and most large provincial schools, compared to very few district and private schools, which have a shorter history of teaching the subject and which are also disadvantaged facility wise.

Generally, performance in French Kenya Certificate of Secondary Education (KCSE) examination is below par: more than $60 \%$ of the candidates who sit for this examination fail to score grade $\mathrm{C}+$ which is the minimum requirement to qualify for entry into university in Kenya (Alliance Française, 2006). It is, however, important to point out that the performance in national and provincial schools is better than performance in other categories of schools. Could this difference in performance be explained from the perspective of French culture?

In Nigeria, attempts to introduce French as a subject in secondary schools have been problematic due to poor teaching and learning environment or culture. Onyeakazi (1983) found that gross inadequacy of necessary materials, facilities and equipment (which is an aspect of the French culture) was a hindrance to this endeavor. Similar conclusion was arrived at by Gicheri (1983) regarding teaching and learning of French in Kenya.

It has to be noted that French culture further entails having high expectations for and recognition of academic and co-curricula achievement, parental involvement, and career guidance and counseling on opportunities in French. The first aspect involves setting challenging goals in academics, like aiming at grade ' $\mathrm{A}$ ' in French, which should be agreed upon by the entire school community (principal, teacher of French, students, and parents) and working towards the attainment of the goals. Individuals who attain their set targets are recognized through rewards that may take simple forms of words of encouragement to tokens of appreciations such as French dictionaries, story books, audio cassettes, T-shirts with writings in French etc. 
On the other hand, high expectations for and recognition of co-curricula achievement implies active participation by students of French in the following French activities: drama and music festivals, French days, cultural exchange programs (e.g. a tour to France), writing articles for "Balafon" magazine, essay writing competitions, and Kenya Broadcasting Corporation (KBC) radio French program. Again any success in these activities calls for a system of reward similar under academic achievement. However, to this end is added the support from without the school, especially by the French government that has, for instance, continued over the years to sponsor the best actor and actress in French drama festivals at national level for a fully paid tour to France. The opinion held by teachers of French is that students who excel in cocurricula activities end up performing well in French Kenya Certificate of Secondary Education (KCSE) examination. This study aims at ascertaining the authenticity of such a belief.

Regarding parental involvement, its relationship with school achievement has been a subject of concern to education officers, principals and teachers in urban and rural society of Kenya. The concern finds a basis in research which is very clear about the benefits, indeed the necessity, of parent engagement. For example, it is argued that students' commitment to schooling (or engagement in learning) is primarily shaped by parents through the "curriculum of the home"; but parent involvement is an alterable variable which can be influenced by school and teacher practices. It may include help in classrooms and on educational visits, and attendance at meetings to discuss children's progress (Fullan, 2001). In an attempt to emphasize to parents the need for their involvement, parent-teacher associations (P.T.A's) were established in Kenya along the lines of developed countries. Unfortunately, the kind of role and level of parental involvement with regard to teaching and learning French has not been well understood by many schools, hence the need for further research to shade more light on the phenomenon.

Career guidance and counseling on opportunities available in French is very important as Kazadi (2006) reveals that students of French foreign language in Kenya are instrumentally motivated. It implies that making students to be aware of what is at stake in the job market for those with knowledge of French will motivate learners to excel in the subject. However, such an argument requires to be backed up by research for it to be credible, thus necessitating this study.

The study determined the relationship between school culture and students' performance in French KCSE examination. The following research questions were formulated to direct the study:

1. What is the relationship between the length of time a school has been offering French subject and students' performance in French in KCSE?

2. What is the relationship between expectation for and recognition of academic achievement in a school and students' performance in French in KCSE? 
3. What is the relationship between expectation for and recognition of cocurriculum achievement in a school and students' performance in French in KCSE?

4. What is the relationship between participation in French co-curricula activities and students' performance in French in KCSE?

5. What is the relationship between parental involvement and students' performance in French in KCSE?

6. What is the relationship between career guidance and counseling on opportunities in French and students' performance in French in KCSE?

\section{Method}

The study was based on correlation design. The samples comprised of students and teachers of French. These were chosen first by use of stratified random sampling technique whereby 16 schools were selected comprising 12 provincial, 2 district and 2 private. Then saturated sampling method was used to select 16 teachers of French (1 teacher per school) and 327 students of French (287 from provincial schools, 24 from district schools and 16 from private schools) from the 16 schools, representing $33.33 \%$ and $34.06 \%$ of the total population, respectively.

The research instrument used in the study was a questionnaire. The students' and teachers' questionnaires were respectively composed of 4 and 5 similar closed-ended type questions, relating to the objectives of the study, that required respondents to indicate how much they agreed or disagreed with each statement by putting appropriate letter (A - Agree, D - disagree or U - undecided) in the bracket at the end of the statement. Questions covered length of time French subject had been offered in a school, academic work, co-curricula activities, support from learners' parents regarding learning and teaching French, and guidance and counseling on opportunities in French.

Once the instrument had been developed, it was field tested on a small group of representative respondents. The pilot test was carried out in 3 secondary schools in Western province to eliminate any ambiguity that existed and to check on content validity of the research instruments.

Returns from teachers and students were $94 \%$ and $100 \%$, respectively. Data obtained from the questionnaires were subjected to descriptive statistics, which included frequencies, means, and percentages. To arrive at means, a positively stated item was scored 3, 2, and 1 for alternative A (Agree), U (Undecided), and D (Disagree), respectively, whereas a negatively stated item was inversely scored, that is, 1,2 , and 3 for alternative $A, U$, and $D$, respectively. The overall mean scores of teachers and students on school culture were subjected to t-test. This was meant to establish whether the teachers' responses differed significantly from the responses of the students. The score of culture for each school was arrived at by averaging teacher' and students' scores. Pearson's Coefficient of Correlation (r) was then used to correlate scores on culture with the schools' scores in 2007 French KCSE examination. 


\section{Results and Discussion}

\section{Results}

Teachers' overall mean score on school culture $(\underline{\mathrm{M}}=1.96, \underline{\mathrm{SD}}=0.47)$ was rated lower than students' overall mean score $(\underline{\mathrm{M}}=2.00, \underline{\mathrm{SD}}=0.18)$. However, a two-tailed test of significance of the difference between the two means resulted in a score $(\underline{t}=0.76)$ lower than the $\underline{t}$ critical value of 1.96 at .05 level, and therefore imply that there was no significant difference in mean score on school culture between teachers and students. Results of the correlation between school culture and students' performance in French KCSE examination are shown in Table 1.

Table 1 Correlation between School Culture and Students' Performance in French KCSE

$\begin{array}{lllllllll}\text { S. NO. } & \text { KCSE } & \text { SC } & \text { LT } & \text { R.A } & \text { R.C } & \text { P.C } & \text { P. S } & \text { G.C } \\ 1 & 6.05 & 2.09 & 3 & 2.96 & 2.73 & 1.78 & 2.23 & 2.22 \\ 2 & 7.8 & 2.33 & 3 & 3 & 2.86 & 2 & 2.94 & 2.06 \\ 3 & 5.63 & 2.15 & 3 & 3 & 1.89 & 1.98 & 2.29 & 2.16 \\ 4 & 4.75 & 1.72 & 2 & 3 & 1.57 & 1.52 & 1.86 & 2 \\ 5 & 3.63 & 1.59 & 3 & 2.93 & 1.5 & 1.4 & 1.57 & 1.46 \\ 6 & 4.5 & 1.51 & 2 & 3 & 1.25 & 1.23 & 1.75 & 1.13 \\ 7 & 6.43 & 2.21 & 2 & 3 & 2.73 & 1.87 & 2.82 & 2.41 \\ 8 & 8.55 & 2.08 & 3 & 2.90 & 1.24 & 2.05 & 1.17 & 1.17 \\ 9 & 3.8 & 1.87 & 1 & 2 & 2.55 & 1.65 & 2.45 & 1.22 \\ 10 & 11 & 2.51 & 2 & 2.93 & 2.44 & 2.39 & 2.65 & 2.12 \\ 11 & 4.6 & 1.99 & 2 & 2.91 & 2.82 & 1.62 & 2.54 & 2.1 \\ 12 & 9.27 & 2.24 & 3 & 3 & 2.38 & 1.92 & 2.93 & 2.23 \\ 13 & 5.08 & 1.79 & 3 & 2.43 & 2.30 & 1.52 & 2.27 & 1.67 \\ 14 & 10.33 & 2.08 & 3 & 2.9 & 1.4 & 2.11 & 1.71 & 1.68 \\ 15 & 4.17 & 1.55 & 1 & 3 & 1.5 & 1.19 & 1.56 & 2.05 \\ \mathbf{R} & - & .78 & .58 & .29 & .07 & .86 & .22 & .23 \\ \mathbf{R} & - & .61 & .34 & .08 & .00 & .74 & .05 & .05\end{array}$


260 Omusonga, T. O., Kazadi, I.M \& Indoshi, F. C.

Key. S. NO. = school number; SC = school culture; LT = length of time a school has offered French; R.A = expectations for and recognition of academic work; R.C = expectations for and recognition of co-curricula achievement; P.C = students participation in French co-curricula activities; P.S = parental support; G.C = career guidance and counseling on opportunities in French.

Table 1 shows that the highest coefficient of correlation was that one of students' participation in French co-curricula activities $(r=.86)$ followed by the overall score on school culture $(\mathrm{r}=.78)$ then length of time a school has been offering French $(\mathrm{r}=$ .58). These 3 variables were the only ones which, according to Kazadi (2006) and Muchielli (1971), yielded significant coefficients of correlation; that is, coefficients of determination $\left(\mathrm{r}^{2}\right)$ exceed $10 \%$.

\section{Discussion of Results}

It is evident that correlation between students' performance in French in KCSE and school culture in general yielded a strong positive relationship between the two variables $\left(\mathrm{r}=.78 ; \mathrm{r}^{2}=.61\right)$. It implies that $61 \%$ of the variance in students' performance in French in KCSE is predictable from the variance of school culture. Remembering the fact that the overall school culture score did not take into consideration the score on length of time a school had offered French, it means that a balanced combination of the rest of school culture variables has a desirable effect on students' performance in French. Schools are therefore encouraged to endeavor to attain this balance.

The following is a discussion of the correlations between students' performance in KCSE and each of the component parts of school culture; that is, the length of time a school has been offering French, expectations for and recognition of academic achievement, expectations for and recognition of co-curricula achievement, parental involvement in teaching and learning of French, and career guidance and counseling on opportunities in French.

\section{Length of time a school has offered French}

There is a tendency towards moderate positive correlation $\left(\mathrm{r}=.58, \mathrm{r}^{2}=.34\right)$ between students' performance in French in KCSE and the length of time French subject has been taught in a school. This means that $34 \%$ of the variance in a school's mean score in French in KCSE is predictable from the variance of length of time a school has been teaching the subject, which in turn is to an extend directly proportional to French curriculum materials, facilities and equipment. The implication is that in order to counter the influence of length of time French has been taught in a school on students' performance in the subject; schools Boards of Governors (B.O.Gs) in conjunction with P.T.As must make available the necessary French curriculum materials, facilities and equipment. Also schools intending to start offering French must first of all put in place these requirements. The scenario witnessed in many schools with the advent of Free secondary education at the beginning of the year 2008, whereby in order to meet the increasing enrolment of students in schools the existing French rooms were converted into classrooms, is something to be discouraged at all costs. 
Expectations for and recognition of academic achievement

There is a very low positive correlation $\left(\mathrm{r}=.29, \mathrm{r}^{2}=.08\right)$ between students' performance in French in KCSE and expectation for and recognition of academic work in a school. Only $8 \%$ of the variance in performance in French is predictable from the variance of expectation for and recognition of academic work by an institution. However, caution must be taken in interpretation of these results because what was meant by expectation and recognition of academic work in this study was a mere perception of respondents regarding things that seem to be most valued in one's school. There is need to conduct a study, which clearly establishes indicators of a high expectation for and recognition of academic work in school and then use the indicators as a basis for establishing the relationship between this variable and performance in French in KCSE.

\section{Expectations for and recognition of co-curricula achievement}

There is almost no correlation $\left(\mathrm{r}=.07, \mathrm{r}^{2}=.00\right)$ between students' performance in French in KCSE examination and expectation for and recognition of co-curricula achievement in a school. Zero percent of the variance in performance in French is predictable from the variance of expectations and recognition of co-curricula achievement by an institution. It must again, however, be noted that the scores in this case on co-curricula activities were averages of teachers and students scores on only one sub-question, which required respondents to state if co-curricula activities seem to be the things valued in one's school. But understandably co-curricula activities in this case were general and not limited to those activities in French. Hence, for example, there can be no relationship between a school that values football and students' performance in French.

\section{Students' participation in French co-curricula activities}

Further correlation analysis between students performance in French in KCSE and students' participation in out of class French activities yielded a very high positive correlation $\left(\mathrm{r}=.86, r^{2}=.74\right)$ meaning that $74 \%$ of the variance in performance in French is predictable from the variance of out of class French activities students actively participated in.

It implies, therefore, that the importance of out of class (co-curricula) activities cannot be underestimated since schools have ceased to be simply transmitters of knowledge and trainers of academic skills. They are also custodians of moral values, of democratic ideals, and of certain aspects of personality development. These latter aspects are referred to as the socializing functions of the school, which are better met through co-curricula activities. Academic work and co-curricula activities therefore have a complementary relationship which schools must take advantage of in an effort to improve students' performance on standardized tests in French. Schools in general and teachers of French in particular must ensure that French students actively take part in French drama, music festivals (reciting French poems), French days, KBC radio French program, cultural exchange programs, writing articles for 'Balafon' magazine and essay writing competitions. 
Parental involvement in teaching and learning of French

A very low positive correlation $\left(\mathrm{r}=.22, \mathrm{r}^{2}=.05\right)$ exists between students' performance in French in KCSE and parental involvement (perceptions that respondents got parental support they so wished with regard to teaching and learning French). Only $5 \%$ of the variance in performance in French in KCSE is predictable from the variance of this variable. Further research on relationship between the two variables, particularly where parental involvement takes into consideration the desired nature and form of support, needs to be carried out in Kenya since theoretical evidence shows that the closer the parent is to the education of the child, the greater the impact on child development and educational achievement (Fullan, 2001). But decisions about the precise nature of parent involvement must take into account cultural, ethnic, and class differences as well as variations related to the age and gender of students. Not all forms of involvement produce positive results; others may be wasteful and counterproductive.

\section{Career guidance and counseling on opportunities in French}

Like parental involvement, the correlation between the variable of career guidance and counseling on opportunities in French and performance on standardized tests (KCSE) yielded a low correlation coefficient $\left(\mathrm{r}=.23, \mathrm{r}^{2}=.05\right)$. There is need to again carry out further research concerning relationship between career guidance and counseling and performance in French. This would enable educationist to determine the kind of emphasis to be accorded career guidance and counseling in curriculum implementation in Kenya.

\section{Conclusions and Recommendations}

The study reached the conclusion that in general school culture has a strong positive correlation with students' performance in French in KCSE examination. The variable of students' participation in French co-curricula activities also has a very high positive correlation with students' performance in French while the variable of the length of time a school has offered French has a relationship that tends towards a moderate positive correlation. It is possible that when students take part in French co-curricula activities, this serves as the opportunity for them to practice the language and perhaps they tend to develop a positive attitude towards French language and culture which boosts their mastery of the language. However, expectation for and recognition of academic achievement, parental involvement in teaching and learning of French, and guidance and counseling on opportunities in French have low positive correlations with students' performance in French in KCSE. But no relationship exists between expectation for and recognition of general co-curricula achievement and students' performance in French.

Based on the conclusions, it is recommended therefore that schools offering French should seek to achieve a balance of a combination of the above variables of school culture. But more emphasis should be put on having students participate in cocurricula activities in French while schools intending to start offering French must first put in place the necessary curriculum materials, facilities and equipment. The 
latter suggestion is meant to compensate for the effect of length of time a school has offered French on students' performance in the subject. And given the novelty of French language to most parents, there is need for schools, particularly through the teacher of French, to induct parents on their roles and levels of involvement with regard to their children learning of French.

\section{References}

Alliance Francaise (2006). Report on the Status of French in Kenya. Unpublished Report. Nairobi: Alliance Francaise.

Fullan, M. (2001). The New Meaning of Educational Change. London: Routledge Falmer.

Gicheri, K. (1983). An investigation of the factors that adversely affect the teaching of French in Kenya secondary schools. Unpublished Postgraduate Diploma in Systematic Curriculum Development Research Project, University of Nairobi.

Kazadi, I. M. (2006). Raisons conduisant les étudiants Kenyans à poursuivre l'apprentissage du francais à l'université in F. K. Iraki (ed.).Research on French Teaching in Eastern Africa: Opportunities and Challenge. Nairobi: United States International University (USIU).

Onyeakazi, D.O. (1983). A study of the attitudes towards French as a subject in secondary grammar schools in Oweri Education Zone (Nigeria). Unpublished PGD in Crriculum Education research project, University of Nairobi. 